\title{
Pigeon Louse Fly or Pigeon Fly, Pseudolychia canariensis (Macquart) (Insecta: Diptera: Hippoboscidae) ${ }^{1}$
}

William H. Kern, Jr. ${ }^{2}$

\section{Introduction}

The pigeon louse fly, Pseudolychia canariensis (Macquart), is a common ectoparasite of pigeons and doves. The louse flies (Hippoboscidae) are obligate blood-feeding ectoparasites of birds and mammals. Both adult males and females feed on the blood of their host. They are adapted for clinging to and moving through the plumage and pelage of their hosts. Strongly specialized claws help them cling to the hair or feathers of their particular host species. Pigeon flies retain their wings for their entire adult life. Others species are wingless (like sheep keds) or lose their wings once the newly emerged adults find a host (deer keds).

\section{Distribution}

This fly is an obligate parasite of birds, especially feral and domestic pigeons and doves (Columbiformes). It is found wherever pigeons are encountered in tropical, subtropical, and temperate areas with mild winters worldwide. It occurs throughout Florida and the Southeastern United States.

\section{Identification}

Pigeon louse flies are brown dorso-ventrally flattened flies that live among the body feathers of pigeons and doves. They are about the same size as house flies ( 5 to $6 \mathrm{~mm}$ head and body length, wings 6 to $7 \mathrm{~mm}$ ) and are very slow fliers. They have a tough exoskeleton that protects them from being crushed by the grooming host.

\section{Life Histories and Habitat}

Louse flies have a very interesting reproductive strategy. The female produces one larva at a time and retains the developing larva in her body until it is ready to pupate. The larva feeds on the secretions of a "milk gland" in the uterus of its mother. After three larval instars, the larva has reached its maximum size, the mother gives birth to the white pre-pupa which immediately begins to darken and form the puparium or pupal shell. The pupa of the pigeon louse fly looks

1. This document is EENY-307, one of a series of Featured Creatures from the Entomology and Nematology Department, Florida Cooperative Extension Service, Institute of Food and Agricultural Sciences, University of Florida. Published: September 2003. This document is also available on Featured Creatures Website at http://creatures.ifas.ufl.edu. Please visit the EDIS Website at http://edis.ifas.ufl.edu. Additional information on these organisms, including many color photographs, is available at the Entomology and Nematology Department website at http://entnemdept.ifas.ufl.edu/. 2. William H. Kern, Jr., Department of Entomology and Nematology, Institute of Food and Agricultural Sciences, University of Florida, Ft. Lauderdale, FL.

The Institute of Food and Agricultural Sciences (IFAS) is an Equal Employment Opportunity - Affirmative Action Employer authorized to provide research, educational information and other services only to individuals and institutions that function without regard to race, creed, color, religion, age, disability, sex, sexual orientation, marital status, national origin, political opinions or affiliations. For information on obtaining other extension publications, contact your county Cooperative Extension Service office. Florida Cooperative Extension Service / Institute of Food and Agricultural Sciences / University of Florida / Larry R. Arrington, Interim Dean 

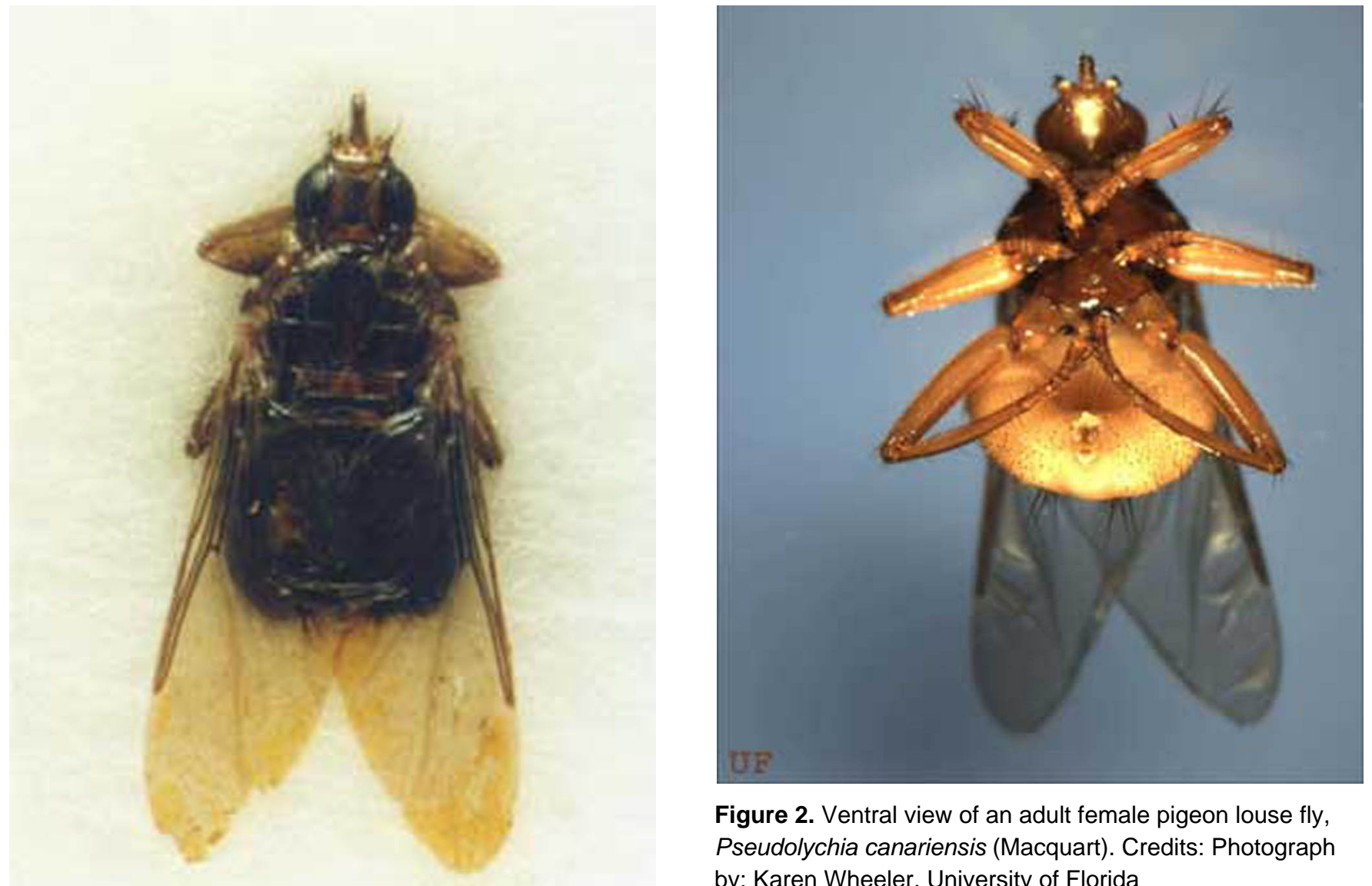

Figure 2. Ventral view of an adult female pigeon louse fly, Pseudolychia canariensis (Macquart). Credits: Photograph by: Karen Wheeler, University of Florida

\section{UF}

Figure 1. Dorsal view of an adult female pigeon louse fly, Pseudolychia canariensis (Macquart). Credits: Photograph by: Karen Wheeler, University of Florida

like a dark brown, egg-shaped seed. The pupa is found in the nest of the host or on ledges where the birds roost. When the fly has completed its metamorphosis, the winged adult emerges from the puparium and flies in search of a host.

\section{Hosts}

This fly is an obligate parasite of birds, especially feral and domestic pigeons (Columba livia) and doves (Columbiformes). Both sexes feed on the blood of the host bird. Theodor (1975) reported that it occurs primarily on pigeons and doves and has been found on many other types of birds in the Old World. He also reported that it only occurs on the domestic pigeon in America. However, it has also been collected from morning doves (Zenaida macroura) in Florida. Pigeon flies very rarely bite humans. Usually it is when a person is handling live pigeons and the

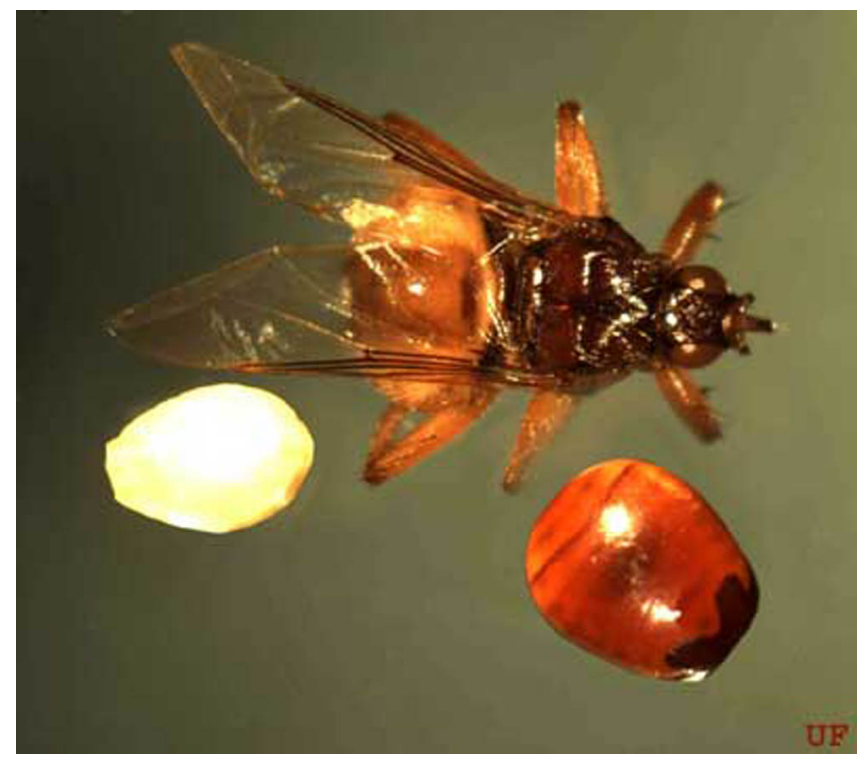

Figure 3. White pre-pupa (terminal larval instar which has stopped feeding and immediately begins to form the puparium when it is delivered by the mother), brown pupa and an adult pigeon louse fly, Pseudolychia canariensis (Macquart). Credits: Photograph by: Karen Wheeler, University of Florida

flies abandon the birds and land on the person. Occasionally pigeon flies bite people after pigeons have been excluded from a structure. Newly emerged 
adults that are unable to find a bird host may go to humans in desperation and bite. Pigeon flies cannot survive on humans and are not known to transmit any diseases to humans. Their bites are comparable to stable fly bites and can be a painful nuisance.

\section{Parasites}

Pigeon flies are commonly parasitized by the mite Myialges anchora (Myialgesidae) in the Old World (Theodor 1975) and this mite likely occurs in the Americas. The pigeon fly is the vector and intermediate host for sporozoite production of the protozoan parasite of pigeons, Haemoproteus columbae (Haemoproteidae: Haemosporidia) (Soulsby 1968). This malaria-like parasite has minimal effects on adult pigeons, but can be fatal to young birds.

Bird biting lice in the suborder Ischnocera (Phthiraptera [Mallophaga]) are often found riding on hippoboscid flies. This is a phoretic association and the lice do not feed on the flies. The lice clasp the legs or setae of the fly's body with their mandibles and hitch a ride to the next bird visited by the hippoboscid fly.

\section{Selected References}

Soulsby EJL. 1968. Helminths, Arthropods, and Protozoa of Domesticated Animals. Williams and Wilkins Co., Baltimore, MD. p.692

Theodor O. 1975. Diptera pupipara; Fauna Palaestina-Insecta I. The Israel Academy of Sciences and Humanities, Jerusalem, Israel. 170 pp. 